\title{
From the laboratory to prime time: science coverage in the main Brazilian TV newscast ${ }^{1}$
}

\author{
Marina Ramalho, Carmelo Polino, Luisa Massarani
}

\begin{abstract}
We analyse the science and technology news reports covered by the Jornal Nacional, the Brazilian newscast with the largest audience, which is broadcast at prime time on a free-to-air channel. The constructed week methodology was used to compose a sample of 72 newscasts, representative of an entire year (from April 2009 to March 2010): 77 science and technology news reports were thus identified, occupying an average of $7.3 \%$ of the newscast's daily broadcasting time, and therefore giving evidence that such matters belong on the JN's agenda. Content analysis has enabled us to observe the following: most reports were focused on announcing research results; the main fields dealt with were medical science and health; the coverage of national research projects ranked highest; researchers and scientific institutes represented the main sources of the news items; scientists were mostly shown in their offices, and as far as interviews are concerned female scientists were a minority. The approach to science was more positive than negative and controversial aspects were scarcely explored.
\end{abstract}

\section{Introduction}

In Brazil, just like in other countries - both developing and developed - television is the chief source of general information for the population, over and above other media. In dealing with access to science ad technology issues, television continues to rank highest among the sources of information, even though the Internet is continuously gaining ground, particularly in developed countries. ${ }^{2,3,4,5}$

In several developing countries, where a significant part of the population has no access to formal education in science, television plays an even greater role in bridging the gap between citizens on the one hand and science and technology information on the other. This is all the more so in Brazil, where science centres and museums, botanical gardens, science festivals and events are mainly restricted to the more industrialised part of the country (southeast Brazil), while television reaches $98 \%$ of the Brazilian territory. It is thanks to the TV that most of the audience is informed about the latest developments in scientific research, scientific policy, new technologies, vaccines and remedies available on the market, among other scientific issues.

According to the 2010 Survey on the Public Perception of Science and Technology in Brazil, commissioned by the Ministry for Science and Technology and by the Museum of Life ${ }^{6}$, a significant part of the Brazilian population (65\%) declares to be interested in science and technology issues, roughly equal to the number of individuals who declare an interest in sports $(62 \%)$, art and culture (59\%), and considerably more than the number of people who are interested in politics $(29 \%)$. These data evidence that there is demand for scientific information among the Brazilian population.

What exactly is the position occupied by science and technology issues in Brazilian TV? And how are these issues dealt with by this medium? Replying to these questions would require comprehensive and detailed investigations examining the TV programmes on science and technology offered by each licensed television channel in Brazil. Yet there are few academic research papers dealing with television in general and with newscasts in particular. For example, in the journal Brazilian Journalism Research, out of the 50 articles on journalism published between 2005 and 2008, only five focused on the news conveyed by the $\mathrm{TV}^{7}$. When searching for papers on science and technology content in the newscasts, the number of Brazilian research publications is even smaller, with most papers dealing with science coverage in general 
in the foreign printed press ${ }^{8,9,10,11,12}$ or with specific scientific issues such as nanotechnology, ${ }^{13,14}$ biotechnology, ${ }^{16,17,18}$ and climate change, ${ }^{19,20,21,22,23}$ mostly in foreign media.

The identification of the position occupied by science in the media, particularly television, would make it possible to check to what extent Brazilians' demand for this kind of information is met. Analysing this type of content would make it possible to single out its main characteristics, its points of strength and those of weakness, thus contributing to improving television science journalism. Furthermore, understanding how the TV harnesses science and conveys it can provide a clue to how TV spectators perceive science and its main players, as several research papers reveal that being exposed to television content does influence, to a certain extent, the perception of viewers with regard to scientific issues ${ }^{24,25}$ - even though it is known that the way in which viewers interpret a message depends on innumerable variables, including his or her own experience and cultural background. ${ }^{26}$ For the reasons outlined above, we believe it is of the utmost importance to carry out research work dealing with the way in which science is addressed by television.

In this article we have identified and analysed a set of science and technology news reports broadcast by the main Brazilian newscast, the Jornal Nacional $(J N)$, on the Rede Globo de Televisão channel, over a one year period (from April 2009 to March 2010). The newscast produced by the major private channel is also the longest standing, as it has been on air since 1969.

\section{Method}

We singled out the Jornal Nacional as it is the newscast with the largest audience in Brazil, broadcast at prime time and with a 57\% average audience share in May 2011, which means that out of 100 spectators watching TV in Brazil while this newscast is being broadcast, 57 tune in to the $J N .^{27}$ Our sample of programmes was collected by means of the constructed week methodology, ${ }^{28,29}$ totalling 72 editions of the Jornal Nacional, representative of a one year period (from April 2009 to March 2010). From these editions we selected science news reports according to a methodology based on the Rondelli ${ }^{30}$ proposal, consolidated by the researchers of the Ibero-American Network for Monitoring and Training in Science Journalism. ${ }^{31}$ In order to qualify for inclusion in the sample considered for the analysis, the science news report $^{32,33}$ had to fulfil at least one of the following requirements: mention scientists, researchers, university professors or experts in general (provided they belong to a scientific institution and were commenting science related issues), or mention research institutions and universities, mention scientific data or research results, mention scientific policy or deal with science communication.

Having identified the science news items, they were submitted to a content analysis based on a protocol jointly developed with members of the Ibero-American Network for Monitoring and Training in Science Journalism. This protocol is aimed at analysing science news reports using different variables, among which the following were selected for this research article: length of the news item, days of the week and newscast section in which they occurred, presence of the news item in the newscast headlines, the scientific fields dealt with, the frames used, the sources and interviewed persons, the gender of interviewed scientists, the interview location, the country where the news item originated from, the presence of statements on the advantages or damages caused by science, the existence of controversies and of context-related information.

\section{Results}

From the 72 selected editions of the Jornal Nacional, 77 science news reports were identified, an average of little more than one report per edition, for an average time of 2 minutes and 15 seconds per news item. Since the average duration of the newscast, excluding advertisements and cartoons, is 30 minutes and 51 seconds, it can be said that in the period covered by the research the Jornal Nacional dedicated $7.3 \%$ of its news time to science. The days of the week with the greatest coverage of science and technology news were Mondays, Tuesdays and Wednesdays, when $59.7 \%$ of the science news items were delivered. This ran counter to our expectations, as we believed that science related issues would be dealt with closer to the weekend, when less news items related to hot topics such as the economy and politics are available, the newscast being broadcast from Mondays through Saturdays.

Out of the 77 science news reports in our research, practically one half $(46.7 \%)$ was mentioned in the opening headlines of the programme, proving that Jornal Nacional attributed some importance to these 
news. Furthermore, $42,8 \%$ of the science news items were delivered in the first section of the newscast, which is usually dedicated to the news with the greatest impact.

We have tried to identify what scientific fields were mostly dealt with in the period of our research and discovered that medical science and health were the ones receiving greatest attention in covering sciencerelated news, as they were the main focus of 34 news items (44.1\% of the total). Next came four fields having roughly the same coverage: exact sciences and earth sciences were covered by 10 news items $(12.9 \%)$; engineering and technology and biological sciences were each addressed in 9 news items $(11.7 \%)$; environmental sciences were the subject of 8 news items $(10.4 \%)$, as shown in figure 1 . Other fields were explored, but to a less representative extent.

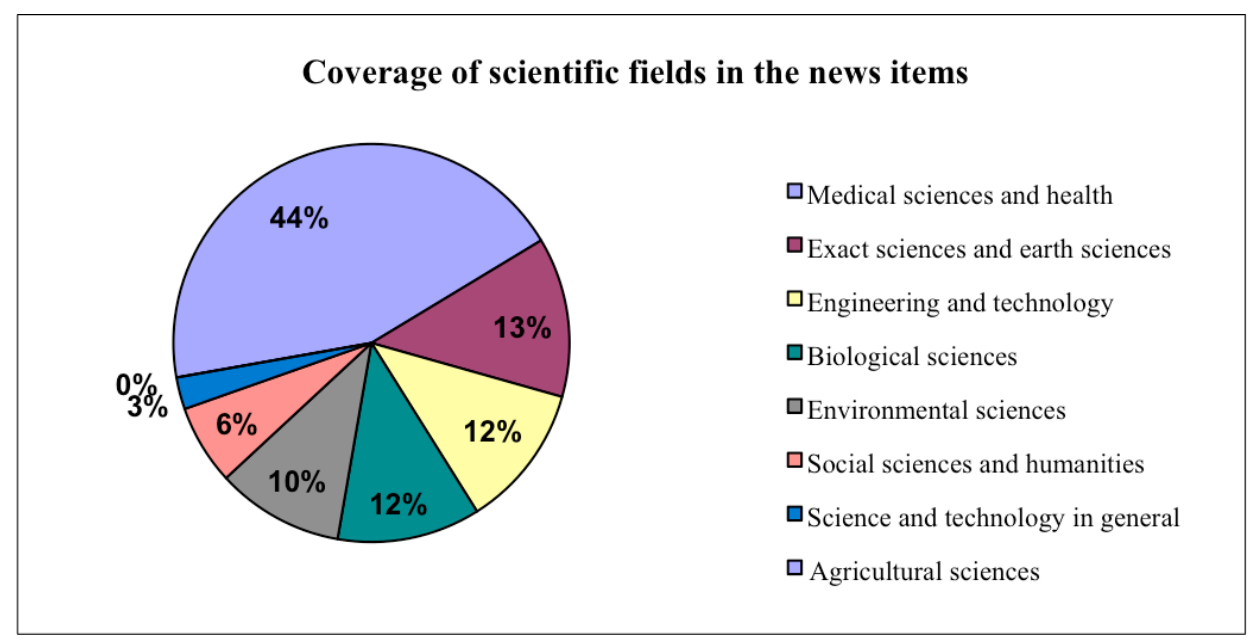

Figure 1. Coverage of scientific fields in the news items in $J N$.

The importance assigned to medical and health issues is also witnessed by the fact that almost half (44.5\%) the science reports announced in the newscast headlines referred to these fields. On the contrary, exact sciences and earth sciences - which ranked second as a source of news items - only represented $5.6 \%$ of scientific issues mentioned in the newscast opening headlines. Furthermore, six out of ten science news reports featured in the first section of the newscast were related to medical sciences and health, while only one in ten concerned earth sciences.

We also paid attention to the frames used, that is to say, the main framing assigned to the news. Our methodology allowed the selection of up to three frames present per news report - hence, the total number of frames dealt with was greater than the absolute number of items. Out of the initial list of 10 frames, we found four to be present in the greatest number of scientific news items: (1) new research results, when the focus of the news item concerned the announcement of a discovery, of a new technological development, of new pharmaceuticals or therapies, etc. (2) impact of science and technology, when the news item conveyed a situation in which research results actually had a direct impact (be it positive or negative) on society, such as improvements in the living conditions of citizens, risks related to scientific applications, among others; (3) scientific background, in which the focus was on the scientific context of the news item, that is to say when previous research was mentioned, or when known data or results were reviewed; (4) political strategy, public policy and legislation. As shown in figure 2, the new research frame was the most used by the Jornal Nacional, as it was applied in 52 news items (67.5\% of the total), which is consistent with the programme profile of giving priority to hard news and scoops. As stated by the anchorman and editor-in-chief William Bonner, "Jornal Nacional's objective is to show the most important events in Brazil and in the world on a given day $(. .$.$) ". 34$

We have found that the science done by Brazilian scientists and research institutions is a priority for the $J N$. Out of the 77 news items in our sample, $40(51.9 \%)$ belonged to this group. ${ }^{35}$ News from scientists and research institutions in North America (narrowing down to the U.S.) ranked second - 25 news items $(32.5 \%){ }^{36}$ Third come news on the science done in Europe: 7 news items $(9.1 \%),{ }^{37}$ as can be seen in figure 3. No news items mentioned scientists or research institutions in Latin America. 


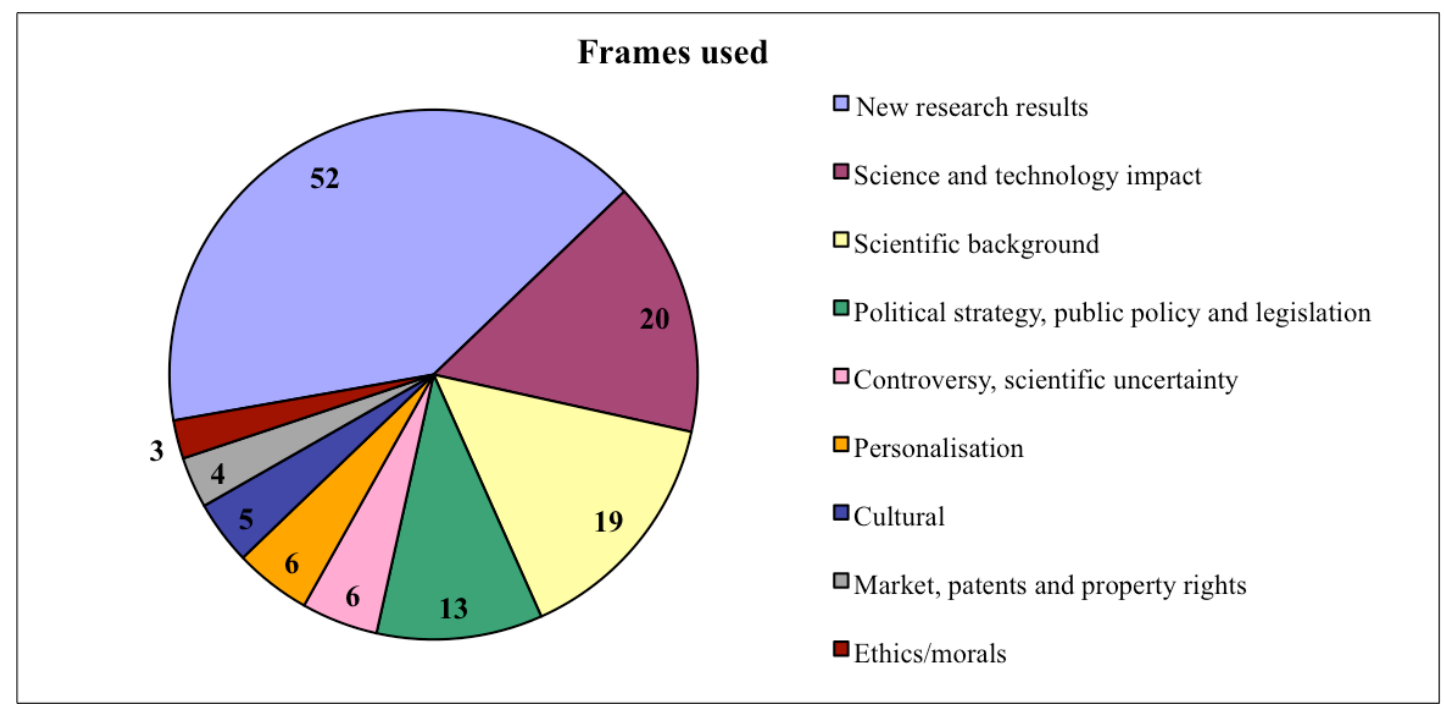

Figure 2. Absolute number of frames used in science news items in the $J N$. Each news item can feature up to three frames.

Differences and similarities can be found between the news items focussing on research work done in Brazil and in the U.S. Among the similarities we have noted in both cases an equivalent proportion of news reports mentioned in the opening headlines and placed in the first section of the newscast (in both cases equal to one half the total). Furthermore, the distribution of news items across the frames is similar between the news reports from these countries. As for the differences, in proportion there are plenty more news items lasting 2-3 minutes on research carried out in Brazil (two thirds of all the news reports from this country). News reports on research work done in the U.S., on the other hand, last less (almost $40 \%$ lasts less than one minute). As for the scientific fields, four reports out of ten on Brazilian research are about medical science and health, followed by biology and environmental sciences, which together account for almost three reports out of ten. Among the news items on the U.S., a greater share deals with medicine and health - six out of ten. Exact sciences and earth sciences rank second, as well as engineering and technology (representing $18.3 \%$ of the news items each). Furthermore, none of the reports on U.S. research concerned biology or environmental sciences.

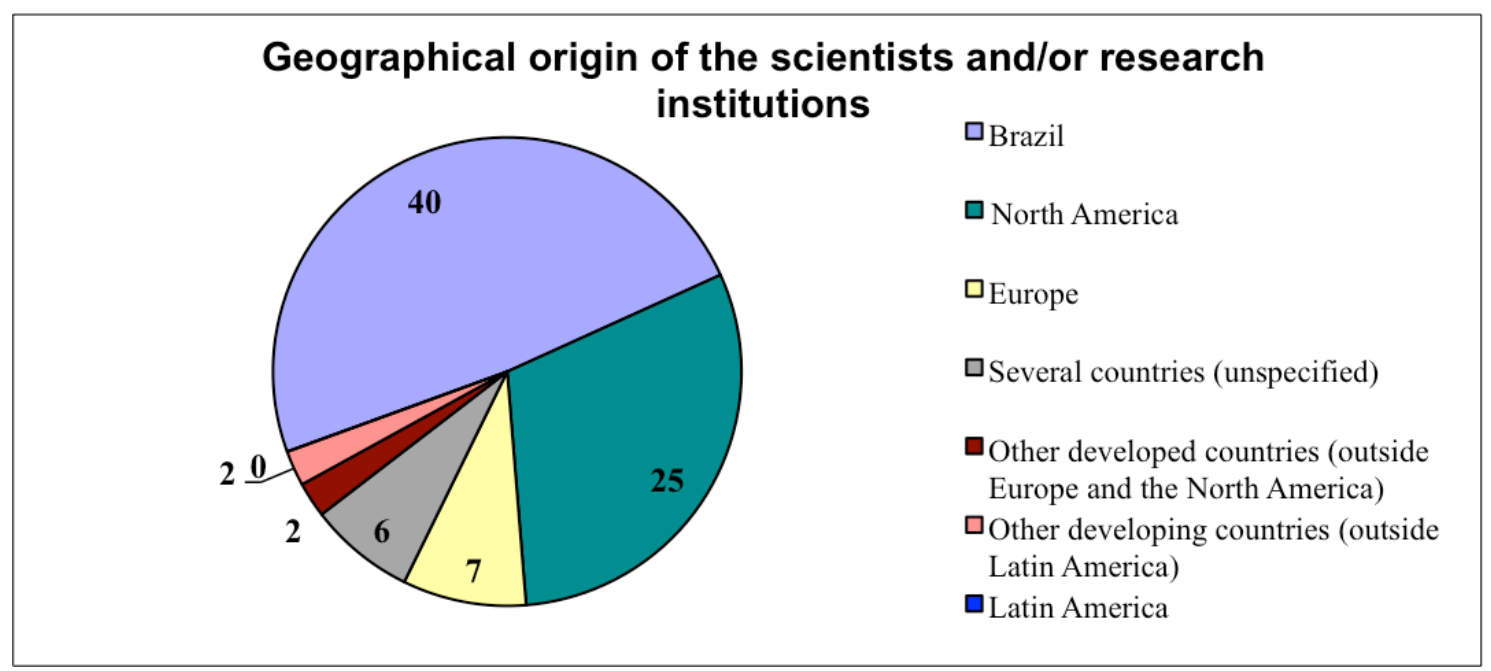

Figure 3. Number of news items represented according to the geographical origin of the scientists or research institutions involved. Since any given news report could involve more than one geographical location (for example, in the case of a collaboration between Brazilians and U.S. researchers), the sum exceeds the number of news items (77). 
Moreover, we found that main sources used to create the news report to be scientists or research institutions, mentioned in 62 news items $(80.5 \%)$. Next came information provided by citizens - 23 news reports $(29,8 \%)$. Information provided by members of the government and experts in general (professionals belonging to a scientific field if not directly connected to a scientific institution) were used in $15(19,4 \%)$ and 12 news reports $(15,6 \%)$ respectively, as can be seen in figure 4.

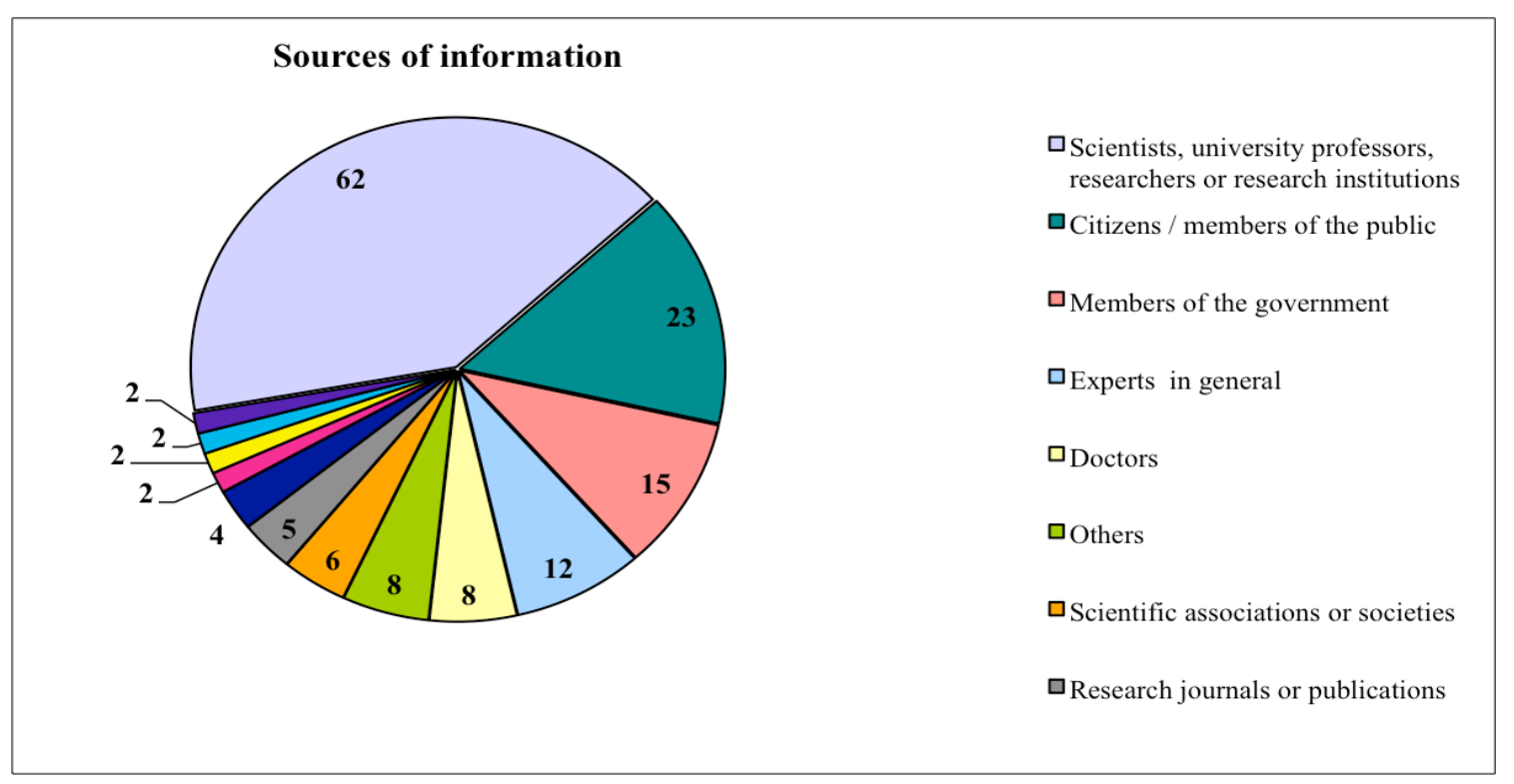

Figure 4. Number of news items per information source. Since any given news report could involve more than one source, the sum of the sources listed in the chart exceeds the number of news items (77).

We sought to single out among the news sources the ones whose voices were also used, that is the ones that explicitly appeared in the report because they granted an interview. Scientists appeared in 39 news reports $(50.6 \%$ of the total), followed by ordinary citizens, who were often asked to voice their opinion and testimony - these were featured in 23 news reports (29.8\%). Members of the government and experts in general appeared respectively in $10(12.9 \%)$ and $12(15.6 \%)$ news items.

From a gender perspective, out of the 45 interviewed scientists little more than one third were women (17). They were interviewed in news items covering several fields - from medical sciences to health, to engineering and exact sciences, traditionally less often connected to typically feminine activities.

We also sought to identify to what extent scientific news items contained images of scientists, whether or not they were interviewed. We believe that analysing these images could be significant for future studies on the social representation of scientists. We noted that 50 scientific news items $(64.9 \%)$ displayed one or more images of scientists, and that they were mostly shown in their office (30.4\% of cases) and in the lab $(25.8 \%)$. They also appeared quite frequently in places where fieldwork had been carried out by them $(16.1 \%)$. In news items on medical sciences and health the share of scientists that appeared in an office (half of all news reports) is higher than the general average. The majority of news items on biological sciences actually shows scientists doing fieldwork.

The approach towards the news items was more positive than negative. We found 34 of them $(44.2 \%)$ mentioned promises or tangible advantages to be derived from science, while only nine of them $(11.7 \%)$ dealt with the hazards and damages resulting from scientific activity. Only five of the news items addressed simultaneously both promises/advantages and hazards/damages. Controversial scientific aspects were also tackled in a small number of news items: eight (10.4\%).

On the other hand, we noted that most of the news was contextualised to a certain extent. For each news item analysed, we checked if some information on the context was also provided - for example, data on the scope of the research, on its duration, methodology, previous studies or future applications. We identified some information of this kind in 51 news items $(66,2 \%)$. It is important to make clear, however, that the protocol used in this research does not enable us to distinguish a well contextualised news item from one 


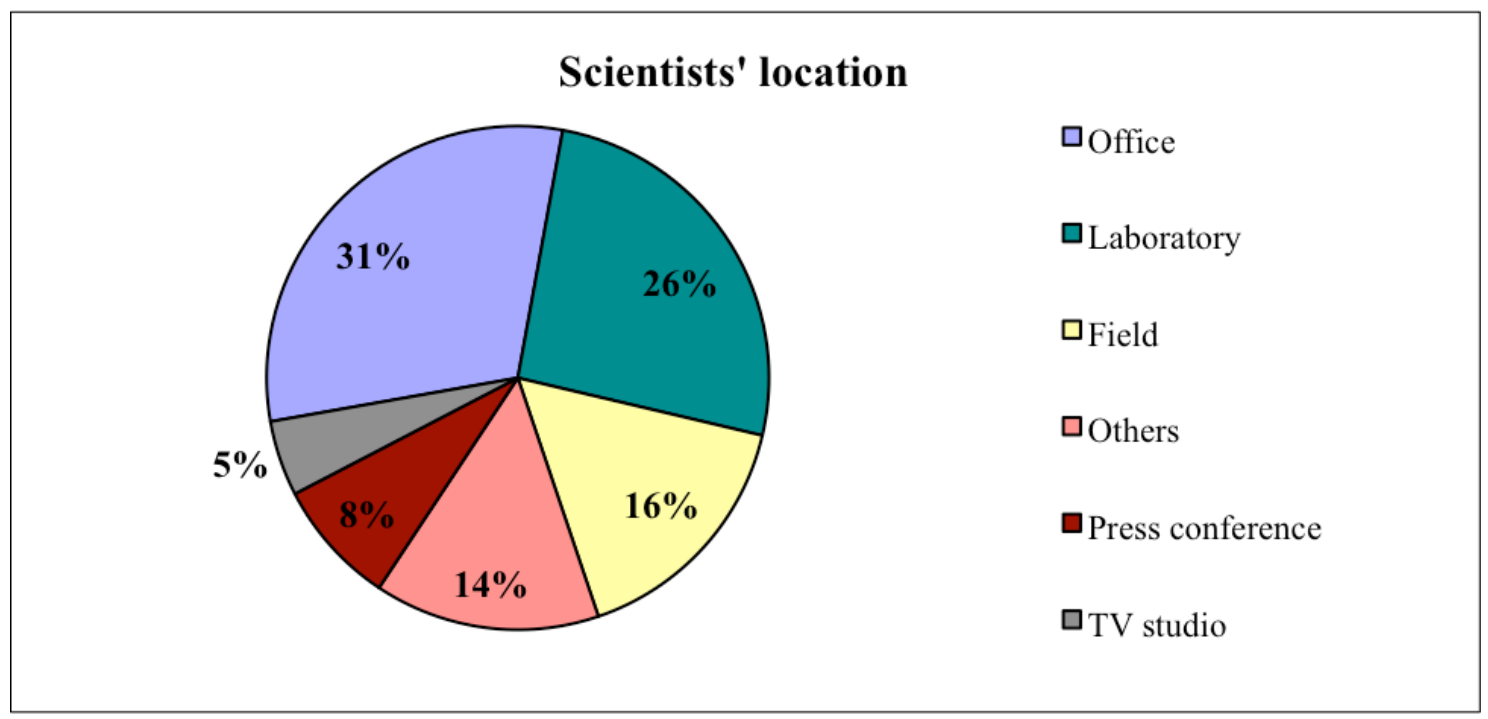

Figure 5. Share of locations in which scientists were displayed in news items by $J N$.

which is less well contextualised. Both were equally codified. However, since 19 of these news items also featured the frame "scientific background", we can infer that these at least $(24,6 \%$ of all news reports) offered greater information on the context.

The share of contextualised news varied according to the different knowledge fields. Approximately eight out of ten news items on medical sciences and health included some information on the context. The same occurred with engineering and technology. About two thirds of the biology news items and those on social sciences had some information on the context, and the same also applies to half of those on environmental sciences. Yet the news involving exact sciences and earth sciences had the least share of news reports containing information on the context: approximately four out of ten.

\section{Discussion and final remarks}

In analysing the coverage of science by Jornal Nacional, one of the features that attracts greatest attention is the emphasis given to medical sciences and health - a trend that had been observed in previous studies. $^{38,39,40,41}$ It is important to note that the sample included only medical sciences and health items which actually featured a scientific research approach, that is to say, that placed the focus on scientific data or methods, or came from sources within the academic community. Hence, we rejected any news related to public health campaigns, services and epidemiology which did not involve any scientific issues. Notwithstanding, the share of news items in these fields remained quite high. Yet research undertaken in the U.K., Canada and Italy ${ }^{42,43,44}$ has proved that medicine is predominant in the social collective imagination in connection with science, and constitutes a field that represents the scientific paradigm. Furthermore, medicine and health are a branch of science that the public perceives to have a direct relationship with their daily life ${ }^{45}$, aside from being subjects which pull emotional strings, as they can encourage hope in the treatment of diseases. That is why they have the potential to attract greater interest for citizens. In Brazil this subject can become even more significant if one considers the fragility of the public health and education systems, as well as the trend among TV channels in the latest decades towards privileging service journalism. Newscasts thus become an ideal means for informing citizens about new illnesses, methods of prevention and therapy.

The number of news reports in the fields of exact sciences and earth sciences, and of engineering and technology was influenced by the fact that 2009 was the year celebrating the fortieth anniversary of man's landing on the moon, and this led to a number of special news reports focussing both on the technology that enabled man to explore outer space and on the study of celestial bodies.

The analysis of the frames enabled us to observe that most of the scientific news concerns the announcement of new research results, which leaves little doubt over the priority of the newscast for hard 
news, at the expense of colder subjects, which tend to explore in greater depth the scientific context in which certain science issues are placed. In other countries, the lack of context-related information is also one of the main criticisms voiced with respect to science and technology coverage by general mass media, ${ }^{46}$ as it is more difficult to understand the news when isolated facts are reported on. Meanwhile, running counter to this trend, the frame for scientific background was present in 19 news items $(24,7 \%)$ and contextrelated information was conveyed in 51 news items $(66,2 \%)$, a result that, for example, confirms the findings of the research by León (2008), ${ }^{47}$ which analysed science coverage by newscasts in five European countries - France, Italy, Germany, Spain and the U.K. - and identified context-related information in $58,7 \%$ of the news items. The effort made to deliver this sort of information bears witness to the newscast's concern with the quality of its content.

We might suppose that the fact that a newscast delivers for the most part brief news items - almost half of the science news reports (49.4\%) lasts less than one minute and fifty-nine seconds, and 37.7\% lasts between two and three minutes - accounts for the lack of context-related information in the news items. On the other hand, it was impossible to detect a direct relation between longer news items and the presence of context related information.

Another relevant characteristic of the coverage by $J N$ was the importance assigned to national science. About one half of the news items $(51.9 \%)$ dealt with research undertaken by Brazilian institutions or scientists, while $32.5 \%$ of the news items focused on North American institutions or scientists (two of them involving collaborations between Brazilians and Americans). Other geographical areas were less relevant. The fact that eight out of ten science news items concerned Brazilian or North American research work proves that the newscast's agenda is greatly concentrated in this geographical area.

The focus on Brazilian research is in contrast with the data from previous studies, which pointed out the emphasis given by the printed press to the science of developed countries. ${ }^{48,49}$ In a research by Almeida et al. (2011), ${ }^{50}$ for example, involving twelve Latin American newspapers from nine countries in the area, seven daily newspapers referred to scientific production in developed countries, while five of them addressed more frequently national research. This can mostly be explained by the fact that many Latin American newspapers are strongly influenced by international news agencies, and by press communiqués distributed by foreign scientific journals and magazines. The emphasis given by Jornal Nacional to national science is also in contrast with the previously mentioned study by León, which revealed that within a list of seven indicators of the value of a news item "geographical closeness" was the least relevant. On the other hand, with reference to television journalism in Brazil, the research by Andrade $(2004)^{51}$ noted that two Brazilian newscasts, among which Jornal Nacional, gave greater emphasis to national research. Meanwhile, it cannot be said that this is a trend either in Brazil or in Latin America, since studies of this kind are scarce and do not allow the identification of any trends. Aside from an ideological issue - enhancing national science -, we believe that this characteristic of the Jornal Nacional in particular can be influenced by the routine production of this channel, which privileges the use of its own images, to the detriment of those offered by news agencies and international research institutions.

Irrespective of its motivations, for us the emphasis placed by $J N$ on national scientific research is a positive fact, as we feel that, at least in theory, this could reflect an agenda bound to national requirements. Furthermore, it makes a contribution to the dissemination of Brazilian research, which is still little know by the Brazilian public. This scant knowledge is reflected in the results of the investigation on the public perception of science undertaken by the Ministry for Science and Technology and by the Museum of Life, which revealed that approximately $80 \%$ of interviewed subjects do not know any institution involved in scientific research in the country, and $87.6 \%$ know no top Brazilian scientist. In such a context, the coverage of Brazilian science by television could contribute to improving this state of affairs.

It is also important to stress that references to scientific research in other countries of Latin America is nonexistent. The lack of information on the science of nearby countries is a long-term characteristic both in Brazilian and in Latin American media, ${ }^{52,53}$ which means that we are more informed about events in developed countries than in nearby nations, with whom we could establish fruitful collaborations.

As for the sources of information mentioned in the news item, we have observed that the main one is either a scientist or a scientific research institution, which is hardly surprising, since they are the main players of scientific activity. On the other hand, a great difference emerges between the presence of these sources and all the others. The second most cited source, ordinary citizens, appears in 23 news items $(29.8 \%)$ and their role appears to be that of lending humanity to the subjects addressed, bringing them closer to everyday life, with opinions and testimonies on their personal experience, while the role of scientists and 
research institutions is to lend legitimacy to the news being covered. The third and fourth most significant sources were the members of the government and experts in general, cited in 15 and 12 news items respectively. The scant presence of these science professionals not directly connected with any scientific institution may bear witness to the newscast's resolve to connect scientists to research institutions, perhaps in order to confer greater legitimacy to its sources. The same trend applies to the "voices" heard by the $J N$. Therefore, the convergence between sources and voices also shows that the same kind of player that gives rise to the construction of a news report explicitly appears in the narration.

As for the gender of the scientists explicitly featured in the news by granting reporters an interview, we have noted that women appear less frequently, which does not reflect the actual state of affairs in the Brazilian research community. According to the latest census by the National Council for Scientific and Technological Development $(\mathrm{CNPq})^{54}$ - one of the main federal government scientific development agencies - in $200849 \%$ of the researchers registered in the directory of Brazilian research groups was female, with $45 \%$ of these groups being headed by a woman scientist. We believe that the majority of male scientists interviewed by the Jornal Nacional is likely to contribute to binding the social representation of scientists to a male stereotype. On the other hand, other aspects generally associated to the stereotype on the scientist's profession - the handling of beakers and sophisticated equipment - appear less frequently than we thought, as most of the time researchers are interviewed in an office. These clues are important, because they enable us to investigate the changes in scientific practice depicted by the television journalism. Future studies could address this issue by staring out from the study of content analysis.

We also noted that the approach towards science tends to be more positive than negative, conferring greater emphasis to the tangible benefits of science and its promises for the future, rather than the potential damages or hazards - a trend resembling that observed in previous studies ${ }^{55,56}$ and which point out to a utilitarian approach to science: science as an end and as a solution to problems, and not as a process or vision of the world. ${ }^{57}$ This optimism is also in line with the views of Brazilians of science and technology as detected by a survey conducted by the Ministry for Science and Technology and by the Museum of Life: $38.9 \%$ of interviewed people in Brazil declared that they believe that science brings advantages alone to society and $42.6 \%$ said that it brings more advantages than disadvantages. We also believe that the fact that scientists and research institutions are the main sources for putting together a news report can contribute to the positive approach by reporters and to the little emphasis given to controversial aspects.

In general we have noted that science and technology issues hold an important position in the agenda of the most important daily newscast in Brazil, concurring towards the outcome that the greater part of the Brazilian population does have access to scientific information to a greater or lesser extent. This fact is consistent with the findings of previous studies, which pointed out to similar trends ${ }^{58,59}$ - although they cannot be directly compared with the findings of this research, as the methodologies used differ - and this indicates the presence of opportunities for scientists and research institutions willing to communicate their research work to the public at large. Meanwhile, qualitative studies would be necessary in order to try to understand just how appropriate these contents are and to what extent they are adjusted to specific segments of the audience. Research undertaken by our group and still ongoing is proceeding in this direction.

Translated by Amanda de Felice

\section{Note and references}

${ }^{1}$ This article is the result of an ongoing research by the Studies on Science Communication of the Museum of Life/House of Oswaldo Cruz/ Oswaldo Cruz Foundation (Fiocruz), supported by the National Council for Scientific and Technological Development (CNPq), by Carlos Chagas Filho Research Support Foundation (Faperj) and by the Ibero-American Programme for Science, Technology and Development (Cyted); it is connected to the Ibero-American Network for Monitoring and Training in Science Journalism (www.museudavida.fiocruz.br/redejc).

2 National Science Foundation (2010), Science and technology: public attitudes and understanding, Science and Engineering Indicators 2010, accessed on 19 April, 2010; available on: http://www.nsf.gov/statistics/seind10/pdf/c07.pdf.

3 European Commission (2007), Special Eurobarometer on scientific research in the media, accessed on 9 May, 2008; available on: http://ec.europa.eu/public opinion/archives/ebs/ebs 282 en.pdf.

${ }^{4}$ H. Jia (2006), TV is top for finding out about science in China, Science and Development Network, accessed on 1 July, 2011; available on: http://www.scidev.net/En/science-communication/news/tv-is-top-for-finding-out-about-science-in-china.html.

5 J.P. Aguirre (2005), La percepción que tienen los colombianos sobre la ciencia y la tecnología - Encuesta 2004, Colciencias, Bogotá. 
${ }^{6}$ Percepção Pública da Ciência e Tecnologia no Brasil, data from a national survey carried out by the Ministry of Science and Technology and by the Life Museum, disseminated in 2010. Accessed on 28 January, 2011; available on: http://www.museudavida.fiocruz.br/media/enquete2010.pdf

7 B. Becker and C. G. Bustamante (2009), The past and the future of Brazilian television news, Journalism 10(1): 45-68.

8 A. Hansen and R. Dickinson (1992), Science coverage in the British mass media: Media output and source input, Communications 17(3): 365-77.

9 E. Einsiedel (1992), Framing science and technology in the Canadian press, Public Understanding of Science 1: 89-103.

${ }^{10}$ M. Bauer, Á. Ragnarsdóttir and A. Rúdólfsdóttir (1993), Science and Technology in the British Press, 1946-1990 - A systematics content analysis of the press, work report.

${ }^{11}$ M.G. Pellechia (1997), Trends in science coverage: A content analysis of three US newspapers, Public Understanding of Science 6: 49-68.

${ }^{12}$ M Bucchi and R. Mazzolini (2003), Big science, little news: science coverage in the Italian daily press, 1946-1997, Public Understanding of Science 12: 7-24.

${ }^{13}$ A. Anderson et al. (2005), The Framing of Nanotechnologies in the British Newspaper Press, Science Communication 27(2): 200-220.

${ }^{14}$ R.S. Kjærgaard (2010), Making a small country count: nanotechnology in Danish newspapers from 1996 to 2006, Public Understanding of Science 19(1): 80-97.

${ }^{15}$ M.C. Nisbet and B. Lewenstein (2002), Biotechnology and the American Media: The Policy Process and the Elite Press, 1970 to 1999, Science Communication 23(4): 359-391.

${ }^{16}$ M. Kohring and J. Matthes (2002), The face(t)s of biotech in the nineties: how the German press framed modern biotechnology, Public Understanding of Science 11: 143-154.

${ }^{17}$ R. Reis (2008), How Brazilian and North American Newspapers Frame the Stem Cell Research Debate, Science Communication 29(3): 316-34.

${ }^{18}$ C. Jurberg et al. (2009), Embryonic stem cell: A climax in the reign of the Brazilian media, Public Understanding of Science 18(6): 719-729.

${ }^{19}$ D. Brossard, J. Shanahan and K. McComas (2004), Are Issue-Cycles Culturally Constructed? A Comparison of French and American Coverage of Global Climate Change, Mass Communication \& Society 7(3): 359-377.

${ }^{20}$ M.T. Boykoff (2008), Lost in translation? United States television news coverage of anthropogenic climate change, 1995-2004, Climatic Change 86:1-11.

${ }^{21}$ B. Takahashi (2010), Framing and sources: a study of mass media coverage of climate change in Peru during the $V$ ALCUE, Public Understand Sci. OnlineFirst February.

${ }^{22}$ J.C. Gordon, T. Deines and J. Havice (2010), Global Warming Coverage in the Media: Trends in a Mexico City Newspaper, Science Communication 32(2): 143-170.

${ }^{23}$ Agência de Notícias do Direito da Infância (2010), Mudanças climáticas na imprensa brasileira: uma análise comparativa de 50 jornais nos períodos de julho de 2005 a junho de 2007- julho de 2007 a dezembro de 2008, V. Vivarta (coord.), Brasília, DF: ANDI.

${ }^{24}$ Y. Hwang and B.G. Southwell (2009), Science TV News Exposure Predicts Science Beliefs: Real World Effects Among a National Sample, Communication Research 36(5): 724-742.

${ }^{25}$ M.C. Nisbet et al. (2002), Knowledge, Reservations, or Promise?: A Media Effects Model for Public Perceptions of Science and Technology, Communication Research 29(5): 584-608.

${ }^{26}$ R. Holliman (2004), Media coverage of cloning: a study of media content, production and reception, Public Understanding of Science 13(2): 107-130.

${ }^{27}$ R. Globo (2011), Audiência/Perfil, Direção Geral de Comercialização, accessed on 21 June, 2011; available on: http://comercial2.redeglobo.com.br/programacao/Pages/jornal-nacional.aspx\#.

${ }^{28}$ K. Krippendorff (1990), Metodología de análisis de contenido. Teoría y Práctica, Ediciones Paidós, Barcelona Spain.

${ }^{29}$ G.H. Stempel and B.H. Westley (eds) (1989), Research Methods in Mass Communication, Prentice Hall, Englewood Cliffs, NJ U.S.A.

${ }^{30}$ D.R.R. Rondelli (2004), A ciência no picadeiro: Uma análise das reportagens sobre ciência no programa Fantástico, São Paulo: Umesp. 147p. Dissertação (Mestrado) - Programa de Pós-graduação em Comunicação Social, Universidade Metodista de São Paulo, São Paulo Brasil.

${ }^{31}$ The Ibero-American Network for Monitoring and Training in Science Journalism was formed in 2009 from a public call of the Ibero-American Programme for Science, Technology and Development (Cyted). Coordinated by the Studies on Science Communication (Museum of Life / House of Oswaldo Cruz / Fiocruz), the network consists of institutions from ten countries in the region: Argentina, Bolivia, Brazil, Colombia, Cuba, Ecuador, Spain, Mexico, Portugal and Venezuela. The authors of this study are members of the network. More information on www.museudavida.fiocruz.br/redejc.

${ }^{32}$ We consider as "news report" any information segment of the newscast with complete sense in itself, like León (2008). This usually includes an introduction by the anchorperson and a sequence of images with the reporter participation. But it may also consist of a text read by the anchorperson, covered or not with images. In some cases, the anchorperson also makes a comment at the end to close the news report.

${ }^{33}$ B. León (2008), Science related information in European television: a study of prime-time news, Public Understanding of Science 17(4): 443-460.

${ }^{34}$ W. Bonner (2009), Jornal Nacional, Modo de Fazer, Editora Globo, Rio de Janeiro Brasil.

${ }^{35}$ From these 40 science news reports, seven also involved scientists or institutions from other countries, besides the Brazilian scientists/institutions.

${ }^{36} \mathrm{Six}$ science news reports that dealt with U.S. research also involved researchers from other countries.

${ }^{37}$ Four of them also mentioned other countries outside Europe.

${ }^{38}$ W. Göpfert (1996), Scheduled science: TV coverage of science, technology, medicine and social science and programming policies in Britain and Germany, Public Understanding of Science 5(4). 
${ }^{39}$ M. Gasher et al. (2007), Spreading the news: social determinants of health reportage in Canadian daily newspapers, Canadian Journal of Communication 32(3-4): 557-574.

${ }^{40}$ P. Verhoeven (2008), Where has the doctor gone? The mediazation of medicine on Dutch television, 1961-2000, Public Understanding of Science 17(4).

${ }^{41}$ C. Almeida et al. (2011), La cobertura de la ciencia en América Latina: estudio de periódicos de elite en nueve países de la región, in C. Moreno (org.), Periodismo y divulgación científica. Tendencias en el ámbito iberoamericano, OEI e Biblioteca Nueva, Madrid Spain.

${ }^{42}$ J. Durant,G. Evans and G. Thomas (1992), Public Understanding of Science in Britain: the Role of Medicine in the Popular Representation of Science, Public Understanding of Science 1(2): 161-82.

${ }^{43}$ E.F. Einsiedel (1992), Framing Science and Technology in the Canadian Press, Public Understanding of Science 1(1): 89-101.

${ }^{44} \mathrm{M}$ Bucchi and R. Mazzolini (2003), Big science, little news: science coverage in the Italian daily press, 1946-1997, Public Understanding of Science 12: 7-24.

45 B. León (2008), Science related information in European television: a study of prime-time news, Public Understanding of Science 17(4): 443-460.

${ }^{46}$ E. Kua, M. Reder and M.J. Grossel (2004), Science in the News: A Study of Reporting Genomics, Public Understanding of Science 13: 309-22.

${ }^{47}$ B. León (2008), Science related information in European television: a study of prime-time news, Public Understanding of Science 17(4): 443-460.

${ }^{48}$ L. Massarani et al. (2005), Science Journalism in Latin America: A case study of seven newspapers in the region, Journal of Science Communication, 4(3).

${ }^{49}$ L. Massarani and B.B. Buys (2008), A ciência em jornais de nove países da América Latina, in L. Massarani and C. Polino (orgs.), Los desafios y la evaluación del periodismo cientifico en Iberomerica, Cyted, Madrid Spain.

See ref 41

${ }^{51}$ L.V.B. Andrade (2004), Iguarias na Hora do Jantar: O espaço da ciência no telejornalismo diário. Rio de Janeiro: UFRJ, 266p. Tese (Doutorado) - Programa Educação, Gestão e Difusão em Biociências, Instituto de Bioquímica, Universidade Federal do Rio de Janeiro, Rio de Janeiro.

52 See ref 49

${ }^{53}$ See ref 41 .

${ }^{54} \mathrm{CNPq}$, Conselho Nacional de Desenvolvimento Científico e Tecnológico (2011), Séries Históricas por Liderança e Sexo, Diretório dos Grupos de Pesquisa do Brasil, accessed on 27 June, 2011; available on: http://dgp.cnpq.br/censos/series_historicas/index_pesquisadores.htm.

${ }_{55}^{5}$ E. Einsiedel (1992), Framing science and technology in the canadian press, Public Understanding of Science 1: 89-103.

${ }^{56} \mathrm{M}$ Bucchi and R. Mazzolini (2003), Big science, little news: science coverage in the Italian daily press, 1946-1997, Public Understanding of Science 12: 7-24.

${ }^{57}$ L. Massarani et al. (2008), A cobertura de ciência por jornais diários: em pauta a pesquisa nacional na Argentina, no Brasil e no México, Razón y Palabra, 65, accessed on 13 June, 2010; available on:

http://www.razonypalabra.org.mx/N/n65/actual/lmassarani.html.

${ }^{58}$ See ref. 51.

59 A.C. Alberguini (2007), A Ciência nos Telejornais Brasileiros (O papel educativo e a compreensão pública das matérias de CT\&I), São Paulo: Umesp. 300p. Tese (Doutorado) - Programa de Pós-graduação em Comunicação, Universidade Metodista de São Paulo, São Paulo.

\section{Authors}

Marina Ramalho is a science journalist and a $\mathrm{PhD}$ student in the field of Education, Communication and Governance of Science at the Institute of Medical Biochemistry/Federal University of Rio de Janeiro. She has a master in Journalism from the Rey Juan Carlos University (Spain) and is currently working at the Studies on Science Communication, Museum of Life, House of Oswaldo Cruz, Oswaldo Cruz Foundation, conducting practical and research activities in science communication.

E-mail: marina.ramalho@gmail.com

Carmelo Polino is a researcher at the Centro REDES (Argentina), an associated researcher of RICYT and the Observatory STS (OEI). Doctorate Program of Universidad de Oviedo (Spain). Master STS Studies (University of Oviedo). Master STS Communication (University of Salamanca). Master STS Studies (University of Quilmes). His research interests are related to sociology of science communication, public perception of S\&T and scientific culture. E-mail: cpolino@ricyt.edu.ar

Luisa Massarani is a Brazilian science journalist, who got a PhD in Education, Communication and Governance of Science at the Institute of Medical Biochemistry/Federal University of Rio de Janeiro (UFRJ). She has been conducting practical activities and research in the area of science and society studies, mainly on mass media studies and public perception of science. She works at the Studies on Science Communication at Museum of Life, which she is now the director of. She is also the Latin American coordinator of SciDev.Net (www.scidev.net). E-mail: lumassa@fiocruz.br. 
How to CITE: $\quad$ M. Ramalho, C. Polino and L. Massarani, From the laboratory to prime time: science coverage in the main Brazilian TV newscast, Jcom 11(02) (2012) A02. 